\title{
Pengaruh Ekuitas Merek Terhadap Minat Beli (Studi Pada Konsumen Oronamin C Di Kota Bandung)
}

\author{
Received: \\ 30 Juli 2020 \\ Revision \\ received: \\ 3 Agustus 2020
}

Accepted:

5 Agustus 2020

\author{
Qonita Firdaus* dan Tintin Suhaeni \\ Jurusan Administrasi Niaga, Politeknik Negeri Bandung, Indonesia
}

\begin{abstract}
:
Amid the growth of functional beverage industry, Oronamin $C$ is still new on the market so the strength of this brand is still not very visible. Therefore, this study purpose is to determine the effect of Oronamin C's brand equity on consumer purchase intention. This study uses an explanatory descriptive method with a quantitative approach to 150 respondents. The data analysis method used is descriptive statistics analysis, correlation, multiple regression, hypothesis testing. The results showed that brand equity and purchase intention were in the good category and both had a significant effect of $65.5 \%$. The dimensions of brand equity, brand awareness and brand loyalty, are in the moderate category, while brand association and perceived quality are in the good category. With the significant influence between perceived quality and brand loyalty on purchase intention, and there is an insignificant influence between brand awareness and brand association on purchase intention.
\end{abstract}

Keywords: brand association; brand awareness; brand loyalty; perceived quality; purchase intention

\section{Pendahuluan}

Laju pertumbuhan perekonomian di Indonesia semakin berkembang terlihat dari semakin meningkatnya berbagai sektor manufaktur di Indonesia. Pada tahun 2019, industri pangan di Indonesia memiliki peran terbesar terhadap produk domestik bruto (PDB) nasional terutama dalam sektor industri minuman yang tumbuh mencapai 7,4\% (Kementrian Perindustrian, 2019). Pertumbuhan yang disorot terutama adalah pada industri minuman, karena dari data yang diambil pada tahun 2018, sebanyak lebih dari 70\% orang Indonesia dalam data Nilai Kontribusi Out Of Home menyukai mengonsumsi minuman siap saji dalam kemasan (Kantar Worldpanel, 2019). Bersamaan dengan hal tersebut, masyarakat membutuhkan asupan gizi yang baik dari pangan yang dikonsumsinya, maka pangan fungsional sangatlah dibutuhkan.

Pangan fungsional dapat diartikan sebagai pangan yang menawarkan peningkatan manfaat kesehatan dan penurunan risiko penyakit karena adanya kandungan dalam produk tersebut yang bermanfaat bagi kesehatan. Beberapa faktor yang meningkatkan permintaan terhadap pangan fungsional, antara lain peningkatan pendapatan, harapan hidup yang lebih lama, tingkat adopsi gaya hidup sehat, dan kemajuan teknologi (Ong et al, 2013).

Di Indonesia sudah berdiri beberapa perusahaan yang bergerak dalam memproduksi dan memasarkan minuman fungsional dalam bentuk kemasan. Salah satunya adalah minuman multivitamin Oronamin C yang diproduksi oleh PT Amerta Indah Otsuka. Oronamin C merupakan produk yang termasuk baru dalam kategori minuman vitamin $\mathrm{C}$, karena baru saja diluncurkan pada tahun 2018 di Indonesia. Namun masih banyak masyarakat yang belum menjadikan Oronamin C sebagai pilihan pertama mereka, salah satunya dilihat dari kategori produk Vitamin $\mathrm{C}$ pada peringkat 
Top Brand Award dimana Oronamin C belum menjadi salah satu merek yang memiliki posisi dalam peringkat tersebut, dimana posisi tersebut diraih oleh beberapa produk pesaing seperti YOU C 1000, Vitacimin dan Enervon C. Berdasarkan hasil survey Top Brand Award tersebut, tidak adanya TBI untuk merek Oronamin $\mathrm{C}$ menandakan bahwa Oronamin $\mathrm{C}$ masih kalah saing dan belum merupakan merek yang kuat di benak pelanggan, sehingga mungkin saja mempengaruhi perilaku pembelian yang dilakukan oleh pelanggan.

Durianto dalam Soebianto (2014) menyebutkan, produk yang secara kompetitif mampu bersaing dan menguasai pasar hanyalah produk yang memiliki ekuitas merek yang kuat. Aaker (1991) juga menambahkan, bahwa perusahaan perlu untukmengendalikan ekuitas merek demi memperkuat kesuksesan perusahaan dalam memperlihatkan keunggulan produk dalam jangka pendek maupun panjang. Walaupun ekuitas merek dapat mengukur tingkat kinerja sebuah merek, Hadi dan Azim (2011) memaparkan yang menentukan keberhasilan suatu produk atau merek di pasaran adalah tingkat pernjualan. Salah satu hal yang dapat memengaruhi tingkat penjualan antara lain adalah minat beli.

Gautam dan Shrestha (2018) menyebutkan apabila terjadi peningkatan terhadap minat beli, berarti kemungkinan terjadi peningkatan juga dalam pembelian merek tertentu, sehingga menunjukkan bahwa minat beli dimaksudkan untuk memprediksi proses penjualan yang lebih baik daripada proses penjualan sebelumnya. Kim dalam Ariffin, et al (2016) lebih jauh menekankan bahwa pembelian dapat dipengaruhi secara langsung oleh ekuitas merek.

Berdasarkan uraian latar belakang tersebut, adapun tujuan dari penelitian ini adalah sebagai berikut:

1. Untuk mengetahui bagaimana ekuitas merek Oronamin $C$ pada konsumen di Kota Bandung.

2. Untuk mengetahui bagaimana minat beli konsumen Oronamin $C$ di Kota Bandung.

3. Untuk mengetahui bagaimana pengaruh ekuitas merek terhadap minat beli konsumen Oronamin C di Kota Bandung.

\section{Kajian Literatur}

\section{Ekuitas Merek}

Aaker (1991) menyebutkan pengertian ekuitas merek sebagai nama atau simbol merek tertentu yang termasuk dalam kelompok asset dan liabilitas yang mampu untuk menambah ataupun mengurangi nilai suatu pada produk atau jasa. Ekuitas merek memberi nilai bagi perusahaan dengan meningkatkan efisiensi dan efektivitas pemasaran, menciptakan kesetiaan konsumen pada merek, meningkatkan keuntungan dan memenangkan kompetisi dengan pesaing lain (Cahyadi \& Santoso, 2014). Ekuitas merek dibangun oleh elemen-elemen atau dimensi-dimensi pendukung yaitu dimensi loyalitas merek, persepsi kualitas, asosiasi merek, dan kesadaran merek (Aaker, 1991).

\section{Kesadaran Merek}

Aaker (1991) menyebutkan kesadaran merek memiliki arti yaitu kemampuan konsumen ketika ia dapat mengenali dan mengingat merek dalam situasi yang berbeda. Aaker (1991) juga menyebutkan bahwa kesadaran merekmenunjukan kemampuan seseorang mengenali atau mengingat kembali termasuk pada bagian kategori produk yang mana suatu merek tertentu berasal. Keller (2013) menyebutkan kesadaran merek terkait denganingatan konsumen, yang dapat diukur dengan kemampuan konsumendalam mengenali merek pada situasi yang berbeda.

Kesadaran merek memiliki beberapa tingkatan yang merupakan indikator capaian oleh sebuah merek di benak konsumen, tingkatan tersebut disebutkan dalam Aaker (1991) sebagai berikut:

1. Top Of Mind: kondisi suatu merek adalah yang paling diingat ketika konsumen ditanya mengenai suatu produk tertentu.

2. Brand Recall: terjadi ketika konsumen bisa dengan mudah memiliki ingatan mengenai merek tertentu tanpa bantuan petunjuk apa pun.

3. Brand Recognition: kompetensi konsumen untuk mengidentifikasikan merek tertentu dengan bantuan sesuatu atau seseorang, seperti simbol, tagline, iklan, dan kemasan. 
Keller (2013) menyatakan bahwa manfaat dari kesadaran merek yang baik adalah peningkatan pada kinerja produk, loyalitas pelanggan lebih besar, tidak rentan terhadap tindakan pemasaran yang semakin kompetitif, dan meningkatan efektivitas komunikasi pemasaran.

\section{Asosiasi Merek}

Aaker menyebutkan (1991) bahwa asosiasi merek adalah sesuatu dalam benak atau ingatan konsumen yang berhubungan dengan merek. Asosiasi merek adalah segala sesuatu yang "terkait" di ingatan seseorang terhadap suatu merek. Tingkat kekuatan asosiasi merek akan lebih kuat apabila konsumen memiliki lebih banyak 'pengalaman' dengan produk tertentu (Aaker, 1991). Suryadi (2015) menyebutkan bahwa asosiasi merek adalah keterkaitan mental pelanggan dengan merek tertentu, dan dapat memberikan keyakinan diri untuk membeli, dan juga membangkitkan rasa nyaman pada konsumen.

Asosiasi merek yang baik dalam Cahyadi dan Santoso (2014) yaitu asosiasi merek yang dapat memberikan pembeda dari sebuah merek dengan merek lainnya, memberikan sebab membeli, perasaan positif yang dapat memengaruhi perilaku pembelian, kepuasan konsumen, juga mengurangi sebab bagi konsumen untuk berpindah ke merek lain, dan memberikan dasar bagi loyalitas merek.

\section{Persepsi Kualitas}

Aaker (1991) mendefinisikan persepsi kualitas sebagai persepsi konsumen secara keseluruhan terhadap kualitas produk atau layanan di bawah merek tertentu. Hal tersebut tidak dapat ditentukan secara obyektif, karena kualitas merupakan bagaimana perasaan pelanggan tentang merek. Li (2017) dalam hal ini juga menyatakan konsumen cenderung merefleksikan persepsi kualitas suatu produk atau layanan ketika akan mempertimbangkan nilai dari suatu produk.

David A. Garvin dalam Aaker (1991) menyebutkan, dalam persepsi kualitas terdapat tujuh dimensi, yaitu: kinerja (performa produk), fitur (elemen atau fungsi produk), kesesuaian dengan spesifikasi (zero defect product), keandalan (reliability dari produk), ketahanan (kekuatan fisik produk), pelayanan (kualitas pelayanan pada konsumen), dan hasil (pemikiran dan perasaan konsumen tentang kualitas suatu produk)

\section{Loyalitas Merek}

Aaker (1991) menyebutkan loyalitas merek adalah ukuran keterikatan yang pelanggan miliki dengan merek, yang mencerminkan kesetiaan pelanggan jika dihadapkan dengan merek lain ketika produk yang biasanya dibeli membuat perubahan terutama dalam harga dan fiturnya. Maka dari itu, Aaker loyalitas merek dapat memiliki pengaruh yang sangat kuat bagi konsumen, dan mengasumsikan loyalitas merek sebagai dimensi inti ekuitas merek (Aaker, 1991).

Durianto dalam Khadafi \& Oktiani (2018) tingkatan loyalitas merek adalah sebagai berikut:

1. Switcher, yaitu konsumen yang seringkali berpindah pada merek lain.

2. Habitual, konsumen secara terus menerus membeli produk didasarkan pada kebiasaan.

3. Satisfied, konsumen yang merasa puas dengan merek tertentu.

4. Liking the brand, konsumen yang menyukai merek didasari dengan pengalaman dan pengetahuan konsumen mengenai merek tersebut.

5. Commited, konsumen berjanji untuk terus membeli dan menggunakan produk.

\section{Minat Beli}

Rasheed et al (2015) menyebutkan minat beli adalah preferensikonsumen untuk membeli produk atau layanan setelah konsumen melakukan evaluasi terhadap produk tersebut. Ferdinad dalam Hanjani \& Widodo (2019) menyebutkan, dimana ukuran minat beli atau yang dapat digunakan dalam mengukur minat beli adalah sebagai berikut:

1. Minat eksploratif, merupakan perilaku seseorang yang cenderung untuk mencari tahu segala macam fakta secara aktif mengenai produk yang diminatinya.

2. Minat referensial, merupakan kecenderungan pada perilaku seseorang untuk merekomendasikan produk.

3. Minat transaksional, merupakan kecenderungan seseorang untuk membeli suatu produk.

4. Minat preferensial, merupakan perilaku seseorang yang sudah memiliki preferensi utama pada satu produk, dan tak akan beralih pada produk yang lain. 
Gautam dan Shrestha (2018) menyebutkan apabila terjadi peningkatan terhadap minat beli, berarti kemungkinan terjadi peningkatan juga dalam pembelian merek tertentu, sehingga menunjukkan bahwa niat beli dimaksudkan untuk memprediksi proses penjualan yang lebih baik daripada proses penjualan sebelumnya. Perilaku pengguna yang sebenarnya dapat diprediksi melalui minat beli konsumen, determinan terbaik untuk menentukan perilaku konsumen adalah minat beli (Abumalloh, et al, 2017). Minat beli konsumen cenderung akan lebih tinggi dengan merek yang sudah mereka kenal (Negahdari, 2018).

\section{Hubungan Antara Ekuitas Merek dengan Minat Beli}

Suryadi (2015) yang menyebutkan ekuitas merek memiliki pengaruh yang positif terhadap minat beli konsumen. Untuk mendukung argumen tersebut, dalam Cahyadi dan Santoso (2014) menyimpulkan berdasarkan penjelasan terhadap dimensi-dimensi ekuitas merek, bahwa kesadaran merek berperan penting dalam minat beli konsumen karena dapat meningkatkan familiaritas konsumen terhadap merek, yang kemudian dapat mengarah pada kemungkinan pembelian. Asosiasi merek mempengaruhi dasar minat beli terhadap suatu merek karena membantu konsumen memperoleh pandangan atas merek untuk dapat menimbulkan alasan untuk membeli, dan menciptakan sikap positif. Demikian pula, persepsi kualitas juga memberikan nilai kepada konsumen karena dapat menjadi titik pembeda dan alasan untuk membeli. Terakhir, loyalitas merek akan membuat konsumen melekat pada merek tersebut. Maka dari itu penelitian ini memiliki kerangka pemikiran sebagai berikut:

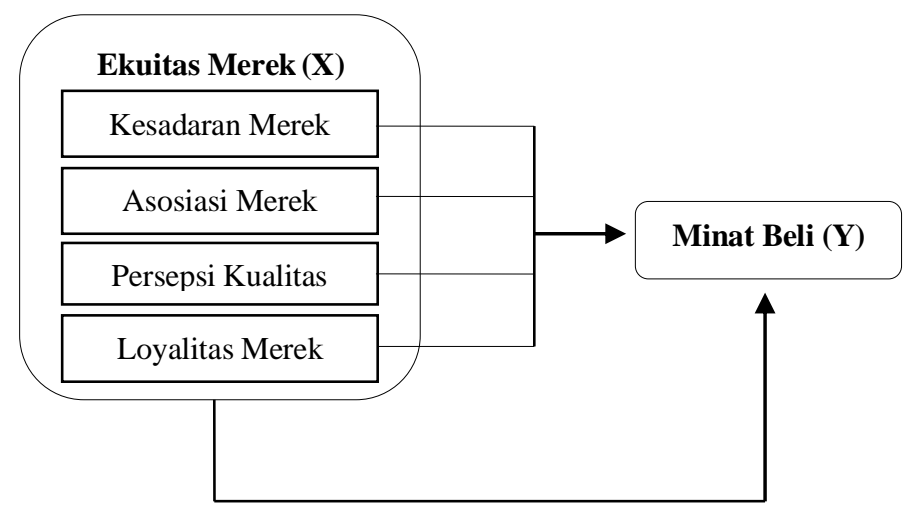

Gambar 1 Kerangka Pemikiran

Berdasarkan kerangka pemikiran di atas, hipotesis penelitian ini adalah sebagai berikut:

Ho : Tidak terdapat pengaruh ekuitas merek terhadap minat beli konsumen pada produk Oronamin C di Bandung.

Ha : Terdapat pengaruh ekuitas merek terhadap minat beli konsumen pada produk Oronamin $\mathrm{C}$ di Bandung.

\section{Metode Penelitian}

Penelitan ini dilakukan dengan metode penelitian deskriptif eksploratif dengan pendekatan kuantitatif yang terdiri dari dua variabel, yaitu variabel ekuitas merek sebagai variabel bebas (X), dan minat beli sebagai varibel terikat (Y). Instrumen penelitian yang digunakan adalah kuesioner yang dibagikan secara online melalui platform Google Form, serta ditunjang dengan hasil obervasi, wawancara tidak terstruktur, dan studi literatur dari jurnal dan buku-buku yang relevan dengan judul penelitian.

Populasi dalam penelitian ini adalah adalah konsumen produk minuman fungsional vitamin $\mathrm{C}$. Sedangkan penarikan sampelnya yaitu non-probability sampling secara purposive sampling menggunakan rumus Hair et al. (dalam Pratita, 2018) dengan tingkat kepercayaan 5\%, sehingga sample yang didapat adalah 150 orang responden konsumen Oronamin $\mathrm{C}$ yang berdomisili di Kota Bandung.

\section{Hasil dan Pembahasan}




\section{Karakteristik Responden}

Karakteristik responden pada penelitian ini dibagi menjadi jenis kelamin, usia dan penghasilan perbulan dan disajikan pada tabel 1 berikut.

Tabel 1 Karakteristik Responden

\begin{tabular}{lcc}
\hline \multicolumn{1}{c}{ Karakteristik Responden } & Frekuensi & (\%) \\
\hline Jenis Kelamin & & \\
Laki-laki & 72 & $48 \%$ \\
Wanita & 78 & $52 \%$ \\
\hline Usia & & \\
$>20$ tahun & 10 & $6.7 \%$ \\
20 - 30 tahun & 84 & $56 \%$ \\
30 - 0 tahun & 32 & $21.3 \%$ \\
40 - 50 tahun & 18 & $12 \%$ \\
$>50$ tahun & 6 & $4 \%$ \\
\hline Penghasilan perbulan & & \\
$<1$ juta & 52 & $34.7 \%$ \\
1 - 4 juta & 47 & $31.3 \%$ \\
$>4$ juta & 51 & $34 \%$ \\
\hline
\end{tabular}

\section{Uji Validitas dan Reliabilitas}

Uji validitas dilakukan pada 30 orang responden. Hasil dari pengujian validitas untuk kedua variabel menunjukkan bahwa semua item dalam instrument penelitian ini valid karena nilai $r$ hitung $>r$ tabel (0.3). Untuk hasil uji reliabilitas kepada sebanyak 30 orang responden dengan teknik alpha cronbach. Nilai cronbach's alpha variabel minat beli dan ekuitas merek adalah reliabel karena memiliki nilai lebih dari 0,60 (Sugiyono, 2013).

\section{Analisis Deskriptif}

Berdasarkan tabel 2 dapat diketahui bahwa nilai rata-rata variabel ekuitas merek adalah sebesar 3,539. Nilai 3.539 tersebut berada pada interval 3.41-4.20 yang termasuk dalam kategori baik. Nilai standar deviasi sebesar 0.878, dimana semakin besar nilai standar deviasi maka semakin besar sebaran atau jarak setiap titik data dengan nilai rata-rata. Hal tersebut memiliiki arti bahwa jawaban responden relatif cukup beragam.

Tabel 2 Hasil Analisis Deskriptif Variabel Ekuitas Merek

\begin{tabular}{llll}
\hline \multicolumn{1}{c}{ Indikator } & Std. Deviasi & Rata-rata & Kategori \\
\hline Kesadaran Merek & 1.019 & 3.32 & Cukup \\
Asosiasi Merek & 0.8426 & 3.688 & Tinggi \\
Persepsi Kualitas & 0.761 & 3.845 & Tinggi \\
Loyalitas Merek & 0.891 & 3.304 & Cukup \\
\hline \multicolumn{1}{c}{ Total } & 3.514 & 14.157 & \\
\multicolumn{1}{c}{ Rata-rata } & 0.878 & 3.539 & \\
\hline
\end{tabular}

Dari keempat dimensi ekuitas merek, dimensi kesadaran merek dan loyalitas merek adalah dimensi dengan rata-rata terkecil. Dimensi kesadaran merek memiliki rata-rata sebesar 3.32, dan dimensi loyalitas merek memiliki rata-rata sebesasr 3.304 yang keduanya termasuk ke dalam interval 2.61-3.40, memiliki arti dimensi kesadaran merek dan loyalitas merek termasuk ke dalam kategori cukup. Sementara itu dua dimensi lain memiliki rata-rata yang besar. Dimensi asosiasi merek memiliki rata-rata sebesar 3.688 dan dimensi persepsi kualitas memiliki rata-rata sebesar 3.845, keduanya berada dalam interval 3.41-4.20 yang berarti dimensi asosiasi merek dan dimensi persepsi kualitas termasuk ke dalam kategori baik. 
Tabel 3 Hasil Analisis Deskriptif Variabel Minat Beli

\begin{tabular}{clll}
\hline \multicolumn{1}{c}{ Indikator } & Std. Deviasi & Rata-rata & Kategori \\
\hline Minat Eksploratif & 0.92 & 3.34 & Cukup \\
Minat Referensial & 0.825 & 3.54 & Tinggi \\
Minat Transaksional & 0.783 & 3.66 & Tinggi \\
Minat Preferensial & 0.865 & 3.20 & Cukup \\
\hline Total & 3.393 & 13.74 & \\
Rata-rata & 0.848 & 3.435 & \\
\hline
\end{tabular}

Berdasarkan tabel 2 dapat diketahui bahwa nilai rata-rata variabel minat beli adalah sebesar 3,435. Nilai 3.435 tersebut berada pada interval 3.41-4.20 yang termasuk dalam kategori tinggi. Nilai standar deviasi variabel minat beli adalah sebesar 0.848 , dimana semakin besar nilai standar deviasi maka semakin besar sebaran atau jarak setiap titik data dengan nilai rata-rata. Hal tersebut memiliiki arti bahwa jawaban responden relatif cukup beragam.

Dari keempat indikator minat beli, indikator minat eksploratif dan minat preferensial adalah indikator dengan rata-rata terkecil. Indikator minat eksploratif memiliki rata-rata sebesar 3.34, dan indikator minat preferensial memiliki rata-rata sebesar 3.20 yang keduanya termasuk ke dalam interval 2.61-3.40, memiliki arti indikator minat eksploratif dan minat preferensial keduanya termasuk ke dalam kategori cukup. Sementara itu dua indikator minat beli yang lain memiliki rata-rata yang terbesar. Yaitu indikator minat referensial dengan rata-rata sebesar 3.54 dan indikator minat transaksional yang memiliki rata-rata sebesar 3.66, keduanya berada dalam interval 3.41-4.20 yang berarti indikator minat referensial dan minat transaksional tersebut keduanya adalah termasuk ke dalam kategori tinggi.

\section{Hasil Analisis Korelasi Berganda}

Korelasi ganda merupakan angka yang menunjukkan arah dan seberapa kuat korelasi antara dua atau lebih variabel ekuitas merek secara bersama-sama terhadap variabel minat beli. Berdasarkan hasil pengolah didapatkan nilai $r$ yaitu sebesar +0.809 yang termasuk dalam interval $0.800-1.00$, dengan demikian dapat dikatakan korelasi antara variabel ekuitas merek dan variabel minat beli secara bersama-sama adalah positif dan termasuk dalam kategori tinggi.

\section{Hasil Analisis Regresi Linear Berganda}

Analisis regresi linear berganda digunakan untuk mengetahui pengaruh atau hubungan secara linear antara dua atau lebih variabel ekuitas merek dengan dengan variabel minat beli. Berdasarkan pengolahan dapat diketahui persamaan regresi yang dapat diperoleh dalam penelitian ini adalah:

\section{Hasil Uji F}

$$
Y=2.172+0.012 X_{1}+0.011 X_{2}+0.389 X_{3}+0.488 X_{4}
$$

Uji F digunakan untuk menguji variabel bebas ekuitas merek (X) secara bersama-sama terhadap variabel terikat minat beli (Y). Berdasarkan hasil perhitungan didapat angka significant pada kolom Sig. sebesar 0,000 atau kurang dari nilai probabilitasnya $0,05(5 \%)$. Apabila dilihat dari nilai $\mathrm{F}$ hitung besarnya adalah 68,762 dengan menggunakan tingkat signifikansi 0,05 serta df1 : $(\mathrm{k} ; \mathrm{n}-\mathrm{k})=\mathrm{F}(4 ; 146)$, maka diperoleh $\mathrm{F}$ tabel sebesar 2,43 yang berarti bahwa nilai Fhitung > Ftabel yaitu 68,762> 2,43, dan signifikansi $0.000<0.05$, sehingga dapat disimpulkan bahwa $\mathrm{H}_{0}$ ditolak. Sementara itu koefiesien determinasi atau nilai $\mathrm{R} 2$ yang dihasilkan adalah 0,655 atau $65,5 \%$.

Sehingga dari uji hipotesis tersebut terbukti terdapat pengaruh signifikan dari ekuitas merek secara keseluruhan terhadap minat beli Oronamin C di Bandung sebesar 65,5\% sedangkan sisanya $34,5 \%(100 \%-65.5 \%=34,5 \%)$ disebabkan oleh sebab-sebab yang lain yang tidak diketahui dan tidak diteliti dalam penelitian ini.

\section{Hasil Uji $t$}

Uji t digunakan untuk mengetahui ada atau tidaknya pengaruh antara dimensi-dimensi ekuitas merek yaitu kesadaran merek $\left(X_{1}\right)$, asosiasi merek $\left(X_{2}\right)$, persepsi kualitas $\left(X_{3}\right)$, dan loyalitas merek $\left(X_{4}\right)$ 
terhadap minat beli (Y). Berikut ini merupakan dasar pengambilan keputusan pada uji t dengan tingkat signifikansi 0,05 :

a. Jika $t$ tabel $<\mathrm{t}$ hitung danprobabilitas signifikan $>0,05 \mathrm{makaH}_{0}$ diterima

b. Jika $t$ tabel $>t$ hitung danprobabilitas signifikan $<0,05$ makaH $_{0}$ ditolak

Dengan perhitungan $\mathrm{t}$ tabel sebagai berikut:

$\mathrm{t}$ tabel $=\mathrm{t}(\alpha / 2 ; \mathrm{n}-\mathrm{k}-1)=\mathrm{t}(0.025 ; 145)=1.97646$.

Berdasarkan hasil perhitungan didapatkan nilai t tabel dimensi kesadaran merek $\left(\mathrm{X}_{1}\right)$ sebesar $0,200(0,200>1,97646)$ maka maka $\mathrm{H}_{0}$ diterima dan signifikansi $0.842(0.842>0.05)$ maka $\mathrm{H}_{0}$ diterima. Sehingga kesadaran merek berpengaruh secara tidak signifikan terhadap minat beli Oronamin C di Kota Bandung.

Dimensi asosiasi merek $\left(\mathrm{X}_{2}\right)$ diperoleh $\mathrm{t}$ tabel sebesar $0.130(0.130<1,97646)$ maka $\mathrm{H}_{0}$ ditolak, dan signifikansi $0.897(0.897>0.05)$ maka $\mathrm{H}_{0}$ diterima. Sehingga asosiasi merek berpengaruh secara tidak signifikan terhadap minat beli Oronamin $\mathrm{C}$ di Kota Bandung. Dimensi persepsi kualitas $\left(\mathrm{X}_{3}\right)$ memiliki nilai $\mathrm{t}$ tabel sebesar 4,916 (4,916. > 1,97646) maka $\mathrm{H}_{0}$ ditolak, dan signifikansi 0,000 $(0,000<0.05)$ maka $\mathrm{H}_{0}$ ditolak. Sehingga persepsi kualitas memiliki pengaruh signifikan terhadap minat beli. Dimensi loyalitas merek $\left(\mathrm{X}_{4}\right)$ memiliki nilai t tabel sebesar 6,795 $(6.795>1,97646)$ maka $\mathrm{H}_{0}$ ditolak dan siginifikansi $0,000(0,000<0.05)$ maka $\mathrm{H}_{0}$ ditolak. Sehingga loyalitas merek memiliki pengaruh signifikan terhadap minat beli.

\section{Kesimpulan}

Berdasarkan tabel 2 diperoleh hasil bahwa secara keseluruhan ekuitas merek berada pada kategori baik. Hal ini mengindikasikan bahwa persepsi responden terhadap ekuitas merek produk Oronamin C di Kota Bandung, mereka telah mengenal dan sadar akan merek, telah memilih merek, mempersepsikan kualitas dan loyalitas secara baik. Prinsipnya responden telah mempersepsikan Oronamin $\mathrm{C}$ merupakan produk yang sudah masuk dan memiliki tempat di hati mereka. Dari penelitian ini, terbukti ekuitas merek memiliki pengaruh terhadap minat beli sebesar 65,5\%. Dari beberapa penelitian yang pernah dilakukan atas pengaruh ekuitas merek terhadap minat beli (Suryadi, 2015; Gautam \& Shrestha. 2018; Harsa \& Syahputra, 2015; Jalilvand \& Mahdavinia, 2011), semua penelitian tersebut membuktikan adanya pengaruh signifikan antara ekuitas merek dan minat beli. Namun memang dimensi-dimensi ekuitas merek yang berpengaruh pada minat beli di setiap penelitian pun hasilnya berbeda-beda, tergantung pada jenis produk yang diteliti, dan di negara apa penelitian tersebut dilakukan, dikarenakan setiap negara atau daerah kebiasaan dan budaya yang berbeda pula (Jalilvand \& Mahdavina, 2011). Dalam penelitian ini sendiri ada beberapa dimensi ekuitas yang termasuk kategori cukup, yaitu kesadaran merek masih dalam kategori cukup atau sedang, yang berarti responden masih belum sepenuhnya menjadikan Oronamin C sebagai pilihan utama dalam benak mereka ketika memilih produk sejenis. Hal tersebut dapat disebabkan oleh berbagai faktor, beberapa diantaranya adalah faktor pesaing, dan dibutuhkannya untuk meningkatkan promosi yang membangun relasi dengan masyarakat. Dimensi loyalitas merek juga masih dalam kategori cukup atau sedang, yang memiliki arti bahwa konsumen masih belum secara rutin atau terus menerus ingin mengonsumsi produk tersebut. Sementara itu, dimensi asosiasi merek dan dimensi persepsi kualitas memiliki nilai rata-rata yang baik. Dapat memiliki arti bahwa konsumen sudah mempunyai persepsi dan asosiasi yang baik dan positif terhadap produk tersebut. Hal ini nantinya dapat memperbesar peluang pada minat pembelian responden di masa yang akan datang.

Berdasarkan kesimpulan di atas terdapat saran yang bermaksud untuk membangun ekuitas merek Oronamin $\mathrm{C}$, antara lain yaitu perusahaan perlu untuk lebih gencar lagi dalam melakukan promosi melalui event atau sponsorship terhadap kegiatan-kegiatan yang diadakan oleh masyarakat seperti festival, pensi, dan kegiatan lainnya. Sehingga dapat meningkatkan kesadaran akan merek Oronamin $\mathrm{C}$ serta menguatkan loyalitas merek pada masyarakat, terutama di Kota Bandung. Perusahaan dapat juga membuka booth di mall, taman, atau fasilitas publik lainnya yang sering dilewati oleh banyak orang untuk meningkatkan eksistensi dan kesadaran merek pada masyarakat, serta membuat slogan atau tagline memakai istilah yang lebih familiar di telinga masyarakat Indonesia, atau berusaha untuk lebih gencar lagi untuk lebih sering mengkomunikasikan tagline yang sudah ada tersebut dengan lebih sering diperdengarkan ke masyarakat lewat iklan atau kegiatan event lainnya. 


\section{Daftar Pustaka}

Aaker, David (1991). Managing Brand Equity. New York: The Free Press.

Abumalloh R., Abu-Ulbeh, W., Ibrahim, O., Nilashi, M. (2017). A Literature Review On Purchase Intention Factors in E-Commerce. Asia International Multidisciplinary Conference (AIMC) 2017

Ariffin, S., Putit, L., Shah, M.,\& Yusof, J. (2016). Factors Influencing Perceived Quality and Repurchase Intention Towards Green Products. Procedia Economics and Finance 37, 391 - 396.

Cahyadi, T. E., Santoso, C. R. (2014). Analyzing the Impact of Brand Equity towards Purchase Intention in Automotive Industry: A Case Study of ABC in Surabaya. iBuss Management. 2(2), 29-39.

Gautam, D. K., Shrestha, S. K. (2018). Impact Of Brand Equity On Purchase Intention Of Smart Phones. Amity Journal of Strategic Management, 1(2), 28-40.

Hadi M, Azim Z. (2011). The Impact of Brand Equity on Purchase Intention and Brand PreferenceThe Moderating Effects of Country of Origin Image. Australian Journal of Basic and Applied Sciences, 5(3), 539-545.

Hanjani, G. \& Widodo, A. (2019). Consumer Purchase Intention: The Effect of Green Brand and Green Knowledge on Indonesian Nestle Company. Jurnal Sekretaris \& Administrasi Bisnis: 3(1), $39-50$.

Harsa, R.S. \& Syahputra (2015). Pengaruh Brand Equity Game Mario Terhadap Minat Beli Konsumen Nintendo Indonesia Pada Konsol Nintendo. E-Proceeding of Management, 2(2), 21502116.

Hutabarat, E. (2017). Pengaruh Promosi Dalam Meningkatkan Volume Penjualan Pada Toko Buku Gramedia Sun Plaza Medan. Jurnal Ilmiah Methonomi, 3(2), 83-95

Jalilvand, Samiei, N. \& Mahdavinia, S. H. (2011). The Effect Of Brand Equity Components On Purchase Intention: An Application Of Aaker's Model In The Automobile Industry. International Business \& Management, 2 (2).

Keller, K. L. (2013) Strategic Brand Management: Building, Measuring, and Managing Brand Equity Fourth Edition. Essex: Pearson Education Limited

Khadafi, R. \& Oktiani, A. (2018). The Effect Of Brand Awareness, Brand Image And Word Of Mouth On Brand Trust And Establishment of Brand Loyalty In C'Bezt FriedChicken Customers, Sub District Genteng, Banyuwangi. Journal of Economic, Business and Accounting, 1(2), 269282

Negahdari, A., Vazifehdoost, H. (2018) Relationships of Brand Awareness, Brand Association and Perceived Quality with Brand Loyalty and Repurchase Intention. Case Studies Journal, 7(1), 4551.

Ong, F. S. et al. (2012). Purchase Behaviour of Consumers of Functional Foods in Malaysia: An Analysis of Selected Demographic Variables, Attitude, and Health Status. Asia Pacific Management Review, 19(1), 81-98.

Pratita, B., Pratiko, H., \& Sutristo. (2018). Analisis Faktor-Faktor yang Memengaruhi Keputusan Pembelian Pelanggan di Kober Bar Malang. Jurnal Pendidikan, 3, 497-503.

Rasheed, F., Younus, S., Zia, A. (2015). Identifying the Factors Affecting Customer Purchase Intention. Global Journal of Management and Business Research: A Administration and Management, 15(2), 9-13.

Soebianto, A. (2014). Analisis Pengaruh Faktor-Faktor Brand Equity Sepeda Motor Merek Honda Terhadap Keputusan Pembelian Pada Konsumen di Kota Bandung. E-Journal Graduate Unpar, $1(1), 14-37$.

Suryadi, D. (2015). The Impact of Brand Equity towards Purchase Intention on PT. X's Candy. iBuss Management, 3(2), 1-8.

\section{*Email korespondensi:}

Qonita Firdaus

qonitanurfi@gmail.com 